\title{
Role of Leadership Competence of the Project Managers for Achieving Project Success in Evaluation
}

\author{
Zebo Sharipova* \\ International Business School \\ Yunnan University of Finance and Economics \\ Kunming, China \\ zebosh_ka@yahoo.com
}

\author{
Ying Zhang \\ International Business School \\ Yunnan University of Finance and Economics \\ Kunming, China \\ angie17@qq.com
}

\begin{abstract}
Demand of human are dynamic and to lead or manage them require to be adapted to or be flexible in each situation depending on location, culture and capacity of those managers (Muller, 2010). The purpose of this paper is to explore theoretical relative importance of project managers' a leadership competences for achieving project success. Based on theoretical approaches of scientists Leadership competences can be assessed as emotional, managerial, and intellectual competences (EQ, MQ, IQ, respectively).
\end{abstract}

Keywords- project manager; leadership competency; project success

\section{INTRODUCTION}

Muller and Turner observe that what is going on in the team through empathy and interpersonal sensitivity and lead the team by example, offering themselves as a role model in terms of what they say and do [1]. As a leader to the project managers have to be very flexible and has a high level of competence such as strong vision on future, sensitivity, good motivator, developer, expert to analyses all kind of situations and have to be able to lead in a team. In this paper we will try explore the role of investigating a leadership competence of project managers for achieving project success.

According to Muller, project manager's leadership competence is the key factor to achieve success and different projects types need different profile of competence of leadership managers [2]. In the literature review on project success factors, it has been found out that the project managers' leadership style and competence has been ignored. This is in direct contrast to the general management literature, which considers effective leadership a success factor in organizations, and has shown that an appropriate leadership style can lead to better performance.

The competency school, developed in the late 1990's, identifies the competencies of effective leaders. According by Boyatsis, competence can be defined as knowledge, skills, and personal characteristics that deliver superior results [3]. From this school, the emotional competence or emotional intelligence construct was developed by Mayer and Salovey

\footnotetext{
* Corresponding author
}

and identified as the most significant of the competencies [4].

As with leadership, project success is another term that has been widely debated lately by scholars in the leadership field. Up until recently, most companies rated project success solely on financial measures such as total cost of project, actual cost versus budgeted cost, etc. According by R. Muller project success is not related directly by competence of leaders of supporting dimensions. They complement the other competencies for a well-rounded personality of the project manager.

Using an extensive review of existing theories and their assessment tools, Dulewicz and Higgs identified 15 leadership dimensions for the competence school, which they clustered under three competences, namely intellectual (IQ), emotional (EQ), and managerial (MQ) [5]. Thus, their 15 leadership dimensions can be used to explain the performance of project managers on different types of change projects.

The focus exact leaders' personal traits in the 1930s to observable behavior of personal attributes in the $1970 \mathrm{~s}$ towards the intellectual exchange and interpersonal relationships at the end of the last century and have been done a lot of research by PMI and PM schools researches [6-9].

\section{LITERATURE REVIEW}

\section{A. Leadership competences in theories}

Successful leaders demonstrate many skills (verbal, analytical, persuasiveness, empathy, etc.), traits (drive, integrity, self-confidence, etc.) and tacit knowledge. However, trait theory research has not been very productive in explain leadership.

The need for effective leadership is accepted among academicians and practitioners of project management. Despite some study in the area of project management leadership, the extent to which leadership influences project success is not clear, nor is the style of leadership apparent.

The field of emotional intelligence is led by two main teams of theorists, Salovey and Mayer and the team of Daniel Goleman and Richard Boyatzis [10]. Salovey and Mayer 
proposed their theory of emotional intelligence in 1990 [11]. These theorists have relied on an instrument they have developed called Mayer - Salovey - Caruso Emotional Intelligence Test (MSCEIT) to validate their specific hypotheses and findings. Goleman and Boyatzis have proposed an inductively based theory of emotional intelligence which has been tested with the Emotional Competence

In the most of situations results as success or fail has depended on as affect of leadership competences of the project manager. Previous studies focused almost solely on the intellectual (IQ), emotional (EQ), and managerial (MQ) capabilities of the project manager [12]. With the leadership stream and the personality stream of research in parallel, the question arises how they combine in the daily work of project managers [13].

Dulewicz and Higgs, show that many of the authors identify up to four types of competence that determine leadership performance Cognitive; Behavioral; Emotional; Motivational. Cognitive competencies are related to Barnard's cognitive functions of the executive. Emotional, behavioral and motivational competencies are related to Barnard's cathectic functions [14].

However, based on Muller's observations and analysis of the literature, Dulewicz and Higgs suggested that three types of competence explain most managerial performance: Intellectual (IQ), Managerial skill (MQ), Emotional (EQ).

According to Muller the above leadership competences, can be broken into cognitive intellectual (intelligence and problem-solving abilities) and managerial (knowledge and skills of management functions). They combined emotional, behavioral and motivational (Barnard's cathertic functions) into one. Elsewhere, Dulewicz and Higgs show that intellectual competence (IQ) accounts for $27 \%$ of leadership performance, managerial competence (MQ) accounts for $16 \%$, and emotional competence (EQ) accounts for $36 \%$.

Furthermore, according to the research of Muller and Turner, the first factor combines the MQ and IQ dimensions plus the EQ dimensions for sensitivity and conscientiousness. The second factor, combines the EQ dimensions for managing resources, self-awareness, influence, and motivation, whereas the third factor includes only intuition, a dimension that was not significantly different between low- and high-performing projects. So, factor 1 was named IQ/MQ, factor 2 was named $\mathrm{EQ}$, and factor 3 was named intuition. Cronbach and alpha values of $0.9,0.8$, and 0.4 , respectively, showed sufficient reliability for the first to factors and led to the exclusion of the third factor. The two factors were saved as variables and used as replacement of the original variables in the further analyses.

\section{B. Leadership in project management.}

According to Bennis, leadership as the ability to make strategic decisions, using communication [15], and the human resource competences of interpersonal relationship, motivation, decision making, and emotional maturity, to mobilize project team members [16]. There are, however a variety of leadership styles that may be applicable for dealing with the many challenges faced by project management [17].
Project managers draw on a variety of leadership approaches that are not necessarily effective, due to the absence of formal leadership training among project managers. The basic principles and methodology that defines the approach to project management are defined by the Project Management Body of Knowledge, but this body does not provide guidelines for leadership in a project environment.

Perhaps the idea of impact of leadership competences of the project managers to achieve success has become a widespread one in recent decades, with many individuals holding different beliefs on it.

The early theories exploring the relationship of leaders and followers were more focused on the leader, particularly how leadership behavior influenced follower attitudes, motivation, and how such behavior 9 affected group effectiveness [18]. Later theories sought to more strongly identify the importance of the follower in supporting leaders in the accomplishment of organizational goals.

The most salient contribution made by the development of behavioral leadership theories was the notion that leaders could be made and that leadership was a skill that could be developed, whereas earlier trait theories posited that leaders were born.

The researchers sought to highlight the importance of project leadership as a key aspect of project successes. Their findings suggested that more demanding market conditions required a stronger focus on leadership, knowledge, and competences to ensure project success. They also believed that successful project outcomes would require an increased emphasis on the organizational and human aspects of project management. Despite the plethora of research, project managers continue to face many challenges and problems concerning leadership, for example, leadership style, stress, uncertainty, motivation, learning, and teamwork.

Hauschildt et al. reported that the success of a project depended more on human factors, such as project leadership, top management support, and project team, rather than on technical factors. They also found that the human factors increased in importance as projects increased in complexity, risk, and innovation. The researchers found that the critical role of the project manager's leadership ability had a direct correlation to project outcomes.

Most recently, the competence school of leadership emerged. It encompasses all the earlier schools. Competence is, hereby, defined as a specific combination of knowledge, competences, and personal characteristics [19].

A leadership style that has been found to enhance the human resource competences of interpersonal relationship, motivation, decision making, and emotional maturity, required to mobilize project team members is participative leadership [20]. Essential to the successful outcome of projects are the project manager and the project team [21-23].

The project manager is responsible for leading the project team towards achieving the desired outcome of the project. The role of project manager combines human and technological resources in a dynamic, temporary organization 
structured to deliver results that include social as well as technological aspects. Leadership in a project environment requires the project manager to integrate and lead the work of the project team. Project management is not an isolated activity, but rather a team effort. A team requires leadership in order to function effectively.

However, Muller suggested, that an organization should have a career structure for project managers, with defined competences at different levels to manage the types of projects it undertakes. Furthermore it assumes the existence of clearly defined success criteria and an understanding of how their values are interpreted in a given culture.

\section{Project success criteria}

Project managers who believe in the success of their projects are more successful than those not believing in it. By looking at sponsors' attitudes, Turner and Muller showed that projects are more successful when sponsors show interest and a healthy level of skepticism towards the project. Similarly, Sewchurran and Barron [24] showed the need for competences on both project managers and sponsors side that appreciates the mutually different environments and works towards common values between the parties [25].

According to Muller, The interaction between human factors and tangible aspects of risk highlights the need to focus closely on human factors as one of the main drivers for risk management, a "change driver" that comes first of all from the need to know how humans perform in challenging environments and in face of risks.

The literature on project success factors, surprisingly, is very quiet about the role of the project manager and his or her leadership style or competence. Leadership style and competence are seldom identified as critical success factors on projects [26].

Then, Muller and Turner in 2007 identified the specific leadership dimensions of the competence school which correlate with success in different types of projects, from which they developed a hierarchy of leadership competences by project type.

Furthermore, by view previous researches is that project is deemed successful when projects are on target, on schedule, on budget, and customers are satisfied [27-30]. Although this definition delineates the traditional approach to project management success concept, a new dimension to defining overall project success has emerged. The new dimension to project success, according to Shenhar, Milosevic at al. takes into consideration the need to link project management and the project's final product [31].

Reports to Nwagbogwu and Shenhar et al. asserted that defining and assessing project success is a strategic management concept that should help to align projects efforts with the short and long-term goals of the performing organization [32-33]. "Table1", shows they argued that the new success criteria involve four dimensions developed from two data sets of 127 projects
TABLE I.

SUCCESS CRITERIA SOURCE

\begin{tabular}{|l|l|}
\hline Success dimensions & Measures \\
\hline Project efficiency & $\begin{array}{l}\text { Meeting schedule goal } \\
\text { Meeting budget goal }\end{array}$ \\
\hline $\begin{array}{l}\text { Impact on the } \\
\text { customer }\end{array}$ & $\begin{array}{l}\text { Meeting functional performance } \\
\text { Fulfilling customers' needs } \\
\text { Solving customers' problem } \\
\text { The customer is using the product } \\
\text { Customer satisfaction }\end{array}$ \\
\hline Business success & $\begin{array}{l}\text { Commercial success } \\
\text { Creating a large market share }\end{array}$ \\
\hline $\begin{array}{l}\text { Preparing for the } \\
\text { future }\end{array}$ & $\begin{array}{l}\text { Creating a new market } \\
\text { Creating a new product line } \\
\text { Developing a new technology }\end{array}$ \\
\hline
\end{tabular}

Munns and Bjeirmi pointed out that the confusion outlined above can be avoided by an improved appreciation of the role of project management within the project. The role of project management is to use the resources available effectively to accomplish a set goal within certain criteria.

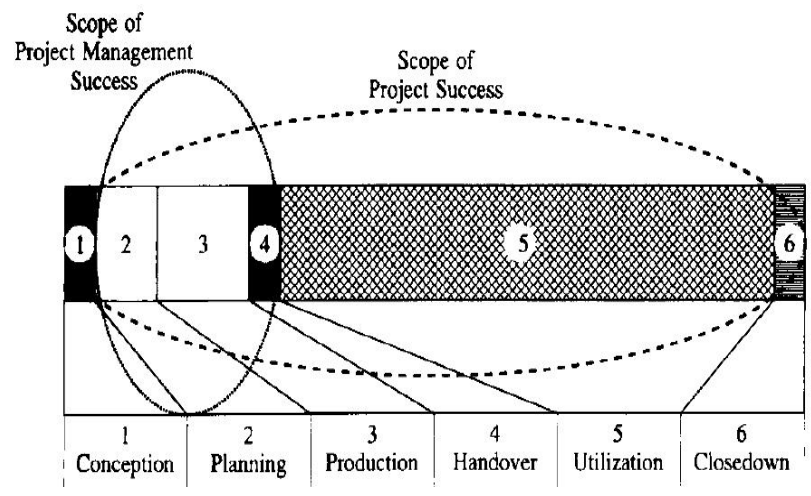

Fig. 1. Scope of Project management success.

Source: Munns and Bjeirmi. (1996)

"Fig. 1," In shortly explanation, the three assessment criteria illustrate the notion that project management techniques are not solely important for project success. Perceived values and client satisfaction will stay for a longer period than implementation. Consequently different criteria for judgment will come to the fore and their significance over implementation will increase with time [34].

Many authors have commented on the need for a wider set of success criteria, but no common set has been agreed yet [35]. Two popular sets of success criteria were developed in recent years. Shenhar and Dvir and Dvir et al. developed a set of success criteria covering novelty, technology, complexity, and pace accomplishments as groups of success criteria for projects [36-37].

Accordingly, Ralf Muller and Rodney Turner, Project success relates to the achievement of planned business results with the project's outcome (typically a new product or service 
in its market). This type of success is typically measured months, if not years, after the project is finished. In other words, depending on the project manager's personality a longor short-term orientation is preferred, which manifests itself in differences in importance assigned to success criteria and differences in leadership styles, which are implemented through leadership competences.

Westerveld examined the link between success criteria, critical success factors, and project types. According by, his list of success criteria included project results (time, cost, and quality), appreciation of the client, project personnel, users, contracting partners, and stakeholders [38]. Wateridge suggested that project managers should first identify the important success criteria for their projects, and then identify success factors that will help them deliver those criteria [39].

Many authors have commented on the need for a wider set of success criteria, but no common set has been agreed yet. Two popular sets of success criteria were developed in recent years. Muller and Turner developed a composite measure of success criteria, taking into account the project team, suppliers, clients, technology, business, and project's own self-defined criteria. Human skill would address the leadership competences of the manager and speaks to his ability to influence direction and effort.

\section{THEORETICAL DEVELOPMENT}

\section{A. Role of investigating of PM' leadership competences for achieving success}

An investigation into project managers' leadership competences towards project success criteria in different projects was done by Muller and Turner. An organization may use risk assumption, risk avoidance, risk retention, risk transfer, or any other strategy (or combination of strategies) in proper management of future events.

As a result, Muller and Turner made conclusion that leadership competences can influence the different aspects of project success. Project success such as various stakeholder groups had been influenced MQ, time, cost, and quality and self-defined criteria had been impacted IQ, project purpose and team satisfaction had been effected by Emotional Intelligence of leadership competence (IQ).

In this case according by previous researches conclusion and by taken into consideration of economic strategy of the countries as a direction to long - term projects and to grow export goods, we have tried explore theoretical approaches and influence of leadership competences IQ, EQ, MQ of project managers to achieving traditional success measures as a time, cost quality by self awareness and motivation. Therefore, the relevance of the study due to a deep rely on the increased public demand and producing goods is necessary to investigate this current scenario by scientists of theoretical problems to form leadership competence of project managers in current industries in the world.

Research proposition - Project managers' IQ, EQ, and MQ has positive and significant effect on project success.

\section{B. The relationship between leadership competences and project success criteria}

This paper follows to identify the impact of positive or negative effect of the project manager's leadership competences to achieve project success of below written terms.

Research proposition - Project managers' IQ, EQ, and MQ reduce the interest of various stakeholder groups and will negatively influence in achieving project success

Muller and Turner, argue that the use of leadership competences and the difference in how they are used by project managers and other managers adds to the understanding of leadership. Using the behavioral leadership theory, which assesses leaders on two major parameters, concern for task and concern for people.

EQ (Emotional Intelligence Quotient) theorists and researchers have proposed varying definitions and meanings of emotional intelligence. However, most theorists appear to include and focus on the same 38 four main components of emotional intelligence: perception of ones and others emotions, regulation of that emotion, and understanding and utilization of that knowledge [40]. These components are "generally accepted to be a combination of emotional and interpersonal competencies that influence our behavior, thinking, and interaction with others [41].

But Sutterfield et al. contend that project managers have to combine technical knowledge and expertise with behaviors and gender sensitive multi-organizational and cross-functional teamwork and communication if successful outcomes are to be achieved.

Whereas Muller argued that to combine the 15 dimensions into the appropriate set for effective leadership within the context of a given project is enabled through the leadership development and practice. This may involve training, experience, mentoring and so on. However, the best mix of leadership dimensions is situational and depends on the project type and the various peculiarities of a project.

Nwagbogwu, on his research, the functional based organization is typically the type of structure used in industrial settings, especially manufacturing settings, where external projects are rarely conducted; according on research reports is that deepens existing knowledge about the importance of different leadership competences. The research showed how each of these competencies influences the different aspects of project success. Managing resources (MQ competence) influences the success perception of the various stakeholder groups, whereas strategic perspective (an IQ competence) impacts the achievement of traditional project success measures like time, cost, and quality and self-defined criteria. Conscientiousness (an EQ competence) impacts the achievement of two different criteria, project purpose, and team satisfaction. Project managers with strong managing resources competencies should be assigned to projects where stakeholders' opinion of project success cannot be compromised. 


\section{SUMMARY \& CONCLUSION}

Literature on project success factors has largely ignored the impact of the project manager, and his or her leadership style and competence, on project success. Furthermore, according Muller conclusion the leadership style and competence of the project manager have no impact on project success, and the unique, novel, and transient nature of projects (as well as the risk involved) means the leader has less of an impact on performance. Then, he giving explanation is this may be because most of the studies asked project managers their opinion and the respondents have not given due consideration to their own impact on project success. Or, it may be because the studies have not measured the impact of the project manager and, thus, not recorded it.

Overall, this study has provided further evidence to support the significance of leadership competences of project managers' for achieving success in current Industry companies in the world in implementation. Clearly further researches will require to confirm these findings and to explore the particular behaviors and their impact on success of projects.

Success could be dimensioned for 4 type related by measurement to Project efficiency, Customer satisfaction, Business success, Future plan. Leadership competency IQ can influenced to the Project efficiency as time-cost-budget, Impact of MQ shows in to business success and future plan, Customer satisfaction can be impressed of EQ.

In conclusion, leadership competencies (IQ, EQ and MQ) can play key factor to achieve success of the project managers and help to make easier performs of project managers in fact. If they would take in competencies for realize of purpose, it can influence for exact trends of success in industries.

This area were not paid attention by most of managers' in the management or other words fully ignored. In future, hopefully in the world be explored and investigated by a scientists and have to strongly argue about positive effect of leadership competency for the managers in career develop and achieving success.

\section{ACKNOWLEDGMENT}

I would like to acknowledge and say thank you to my supervisor Dr Ying Zhang for being patient with me and for her continuous guidance.

\section{REFERENCES}

[1] J.R. Turner, and R. Muller, "The project manager's leadership style as a success factor on projects: a literature review," Project Management Journal, vol. 36, 2005, pp. 49-61.

[2] R. Muller, and K. Judgev, "A retrospective look at our evolving understanding of project success," Project Management Journal, vol. 36, 2005, pp 19-31.

[3] R. Boyatzis, "The Competent Manager - A Model for Effective Performance," Wiley, New York, 1982.

[4] V. Dulewicz, and M. Higgs, "Emotional intelligence-A review and evaluation study," Journal of Managerial Psychology, vol. 15, 2000, 341-372.
[5] V. Dulewicz, and M. Higgs, "Assessing leadership styles and organizational context," Journal of Managerial Psychology, vol. 20, 2005, pp. 105-23.

[6] R. Muller, and T. Rodney, "Attitudes and leadership competences for project success," Baltic Journal of Management, vol. 5, 2010, pp. 307 329.

[7] L. Crawford, and J.R. Turner, "Assessing and developing the project management competence of individuals," in Turner, J.R. (Ed.), People in Project Management, Gower, Aldershott, 2003.

[8] Goleman, and Boyatzis, "Primal Leadership: Learning to Lead with Emotional Intelligence," Harvard Business School Press, Boston, MA, 2002.

[9] Boyatzis, Crawford, Goleman, and Turner, "Primal Leadership: Learning to Lead with Emotional Intelligence," Harvard Business School Press, Boston, 2002.

[10] D. Goleman, "Emotional Intelligence," Bantam Books, New York, 1995.

[11] G. Matthews, M. Zeidner, and R.D. Roberts, "Emotional intelligence," science and myth, Cambridge, MA: MIT Press, 2002.

[12] P. Salovey, and J.D. Mayer, "Emotional intelligence. Imagination, Cognition and Personality," vol. 9, 1990, pp. 185-211.

[13] R. Muller and R. Turner, "Attitudes and leadership competences for project success,” Baltic Journal of Management, vol. 5, 2010, pp. 307 329.

[14] M. Higgs and J. Wren, "The Leadership of Change: A study of change Leadership within the UK Royal Air Force," Henley Management College Greenland, UK, vol. 15, 2005, pp. 6-10.

[15] V. Dulewicz, and M. Higgs, "Design of a new instrument to assess leadership dimensions and styles," Henley Working Paper HWP 0311, Henley Management College, Henley-On-Thames, 2003.

[16] W. Bennis, and B, Nanus, "Leaders: The strategies for taking charge," New York: Harper \& Row, 1985.

[17] T.W. Zimmerer, and M.M. Yasin, "A leadership profile of American project managers," Project management Journal, vol. 29, pp. 31-38.

[18] M. Porthouse, C. Dulewicz, “Agile project managers' leadership competencies," In: Henley Management College Working Paper Series HWP 0714, Henley Management College, Henley-on-Thames, UK, 2007.

[19] B.M. Bass, "Leadership and performance beyond expectations," New York: Free Press, 1985.

[20] L. Crawford, and J.R. Turner, "Assessing and developing the project management competence of individuals," in Turner, J.R, People in Project Management, Gower, Aldershott, 2003.

[21] H. Kerzner, "Project management: A systems approach to planning, scheduling, and controlling," Hoboken, Wiley, 2006.

[22] C.A. Berg and P. Kalezynski, "Practical intelligence and problems solving: Searching for perspective," In F. Blanchard - Fields and T. M. Hess, Perspectives on cognition in adulthood and aging, 1996, New York: McGraw Hill, pp. 323-357.

[23] J. Blake, and J.S. Mouton, "The managerial grid," Houston, TX: Gulf Publishing Company, 1964.

[24] W. Leban, "The relationship between leader behavior and emotional intelligence of the project manager and the success of complex projects," 2003.

[25] J.R. Turner, and R. Muller, "Communication and co-operation on projects between the project owner as principal and the project manager as agent," European Management Journal, vol. 22, 2004, pp. 327-36.

[26] R. Muller, and J.R. Turner, “The impact of principal-agent relationship and contract type on communication between project owner and manager," International Journal of Project Management, vol. 23, 2005, pp. $398-403$.

[27] J. Phillips, "Program management professional all-in-one exam guide," Emeryville, CA: McGraw-Hill, 2009.

[28] J. Gido, and J. Clements, "Successful project management," Mason, OH: Thomson South-Western, 2006.

[29] B. Hedeman, G. Heemst, and H. Fredriksz, "Best practice: Project management based on prince2," San Antonio, TX: Van Haren, 2005. 
[30] S.W. Hughes, D. Tippett, and W.K. Thomas, "Measuring project success in the construction industry," Engineering Management Journal, vol. 16, 2004, pp. 31-37.

[31] A.J. Shenhar, D. Milosevic, D. Dvir, and H. Thamhain, "Linking project management to business strategy," PM Network, vol. 21, 2007, pp. 9191.

[32] D. Nwagbogwu, "The correlation between project management effectiveness and project success," Walden University, College of Management and Technology, 2011.

[33] A.J. Shenhar, D. Dvir, O. Levy, and A. Maltz, "Project success: A multidimensional strategic concept. Long Range Planning," vol. 34, 2001, pp. 607-32.

[34] Munns and Bjeirmi, "The role of project management in achieving project success," International Journal of Project Management, vol. 14, 1996, pp. 81-87.

[35] R. Atkinson, "Project management: cost, time and quality, two best guesses and a phenomenon it's time to accept other success criteria," International Journal of Project Management, vol. 17, 1999, pp. 337-43.
[36] A. Shenhar, and D. Dvir, "Reinventing Project Management," HBS, Boston, MA, 2007.

[37] D. Dvir, A. Sadeh, and A. Malach-Pines, "Projects and project managers: the relationship between project manager's personality, project, project types, and project success," Project Management Journal, vol. 37, 2006, pp. 36-48.

[38] E. Westerveld, "The project excellence model: linking success criteria and critical success factors," International Journal of Project Management, vol. 21, 2003, pp. 411-18.

[39] J. Wateridge, "How can IS/IT projects be measured for success?" International Journal of Project Management, vol. 16, 1998, pp. 59-63.

[40] J.V. Ciarrochi, A.Y. Chan, and P. Caputi, "A critical evaluation of the emotional intelligence construct, personality and individual differences," Journal of Personality and Social Psychology, vol. 28, 2000, pp. 539-561.

[41] W.D. Macaleer, and J.B. Shannon, "Emotional intelligence: How does it affect leadership?" Employment Relations Today, vol. 29, 2002, pp. 919 